\title{
The Effect of Bovine Virus Diarrhoea Virus on Reproduction in Recently Infected Norwegian Dairy Herds
}

\author{
By B. Fredriksen ${ }^{1}$, S.A. Ødegaard ${ }^{1}$ and T. Løken ${ }^{2}$ \\ ${ }^{1}$ Department of Reproduction and Forensic Medicine, and ${ }^{2}$ Department of Large Animal Clinical Sciences, Nor- \\ wegian College of Veterinary Medicine, Oslo, Norway.
}

\begin{abstract}
Fredriksen B, Ødegaard SA, Loken T: The effect of bovine virus diarrhoea virus on reproduction in recently infected Norwegian dairy herds. Acta vet. scand. 1998, 39, 99-108. - A group of 32 dairy herds, recently infected with bovine virus diarrhoea virus (BVDV), was compared with a control group consisting of 75 BVDV free herds during a 3-year-period. Variables related to reproduction were registered. Results of multiple antibody examinations in bulk milk as well as samples of milk and blood from younger animals were used to select the herds. The incidence of abortions was statistically significantly different in the 2 groups, while the number of stillbirths, weak born calves, and congenital anomalies was not. Other variables such as percentage of non return, average number of inseminations per cow and calving interval showed during the study a trend to improve in the BVDV group, while they remained stable in the control group.
\end{abstract}

abortions; stillbirths; weak born calves; anomalies; non return; calving interval; antibodies.

\section{Introduction}

Bovine virus diarrhoea (BVD) was first described by Olafsson et al. in 1946, and has the last 2 decades in particular become well known around the world. The complexity of the infection and the clinical symptoms it causes have resulted in a dividing of the syndrome into several manifestations: Acute BVD, immunosuppression inducing secondary infections, reproductive failure, a weak calf syndrome, persistent infection with or without symptoms, and acute and chronic mucosal disease (Baker 1987). Many authors have described the adverse effects bovine virus diarrhoea virus (BVDV) can have on reproduction (Løken \& Daling 1994, Kendrick 1971, Done et al. 1980, Roeder et al. 1986), including abortions (Mur- ray 1991, Casaro et al. 1971), stillbirths (Houe \& Meyling 1991), congenital anomalies, including intrauterine growth retardation, and early reproductive failure (Virakul et al. 1988, Houe \& Meyling 1991, McGowan et al. 1993, Carlsson et al. 1989). These effects are well documented, but since investigations are usually performed in herds with defined reproductive problems or with experimentally infected animals, it is hard to state the effect on an average herd being infected with the virus.

A combination of analysis for BVDV antibodies in bulk milk, milk from heifers and blood from calves can be used to identify and select recently infected herds. Antibody examination of bulk milk is a simple and unexpensive way to 
identify herds where a considerable proportion of the milking cows have antibodies to the virus. Detection of antibodies in milk and blood from the young stock indicates a more recent infection in the herd. Such recent infection between young animals is most often caused by the presence of one or more persistently infected animals in the herd. The aim of the present study was to describe the effect of BVDV on reproduction in recently infected Norwegian dairy herds.

\section{Materials and methods \\ Herds}

All the herds in the study were dairy herds with Norwegian Red as the predominant breed. Herds from 10 different counties in Norway were included. Initially, the herds were included in the study according to results of 2 examinations for BVDV antibodies in bulk milk less than 18 months apart (Table 1). The BVDV group consisted initially of 75 herds in which the first sample was negative for antibodies against BVDV, while the second sample was positive. Four herds were closed down in the period of the study and is excluded from the dataset $(n=71)$. All herds which were negative for BVDV antibodies in a pooled milk sample from 2-5 heifers $(n=25)$ this year, or a pooled blood sample from 3-5 calves $(n=9)$, are characterized as drop outs (Table 1). The absence of antibodies in samples from the young stock indicates that the presence of antibodies in the bulk milk may be caused by other factors than persistently infected animals in the herd, such as acute infection or purchase of antibody positive animals (Fredriksen et al. 1998). In 13 herds, samples from calves and heifers were not examined, and so the BVDV status in these herds was more uncertain. If a bulk milk sample in these herds was negative in one of the next 2 years, the herd was excluded from the study as a drop out $(n=5)$. Accordingly, the final number of herds in the BVDV group is 32 . The control group consisted of similar herds which were negative for BVDV antibodies in bulk milk at both examinations less than 18 months apart. These herds were selected county wise in order to match the number of infected herds in each county. Within the counties the sampling was done by random sampling from all herds filling the inclusion criterium. Two herds closed down during the study period and are excluded from the data. Herds with BVDV antibodies in bulk milk 1 or 2 years later $(n=9)$ were excluded as drop outs (Table 1), and the final number of herds in the control group is 75 .

\section{Examination for antibodies}

All milk samples, stored at $-20^{\circ} \mathrm{C}$, were examined for antibodies against BVDV by an indirect enzyme-linked immunosorbent assay (ELISA) as described by Niskanen et al. (1989) (Svanovir ${ }^{\circledR}$, Svanova Biotech, Sweden) ${ }^{1}$. The results were automatically read and given as absorbance values at $450 \mathrm{~nm}$. Bulk milk samples with values $<0.25$ were characterised as negative for antibodies to BVDV, while those with a level $\geq 0.25$ were characterised as positive. Pooled milk samples from heifers were characterised as positive if the absorbance value was $\geq 0.1$ This value was set lower than for bulk milk because of the purpose of detecting even single seropositive animals. Pooled blood samples from calves were similarly examined for BVDV serum antibodies by an indirect ELISA (Juntti et al. 1987), and characterised as positive when the absorbance value was $\geq 0.25$.

\footnotetext{
${ }^{1}$ Most of the bulk milk samples were analysed by The Veterinary Institute in Oslo, Sandnes, Trondheim or Harstad, while a few samples were analysed by the Norwegian Red Cattle Association (NRF) in Hamar.
} 
Table 1. Examinations for ELISA antibodies against BVDV in milk and blood in a total of 155 dairy herds, during the period of 1992-1995. These results grouped the herds into a BVDV infected group, and a not infected control group. The numbers in the table refer to number of herds with positive or negative results on the respective examinations.

\begin{tabular}{|c|c|c|c|c|c|c|}
\hline B 1992 & B 1993 & H 1993 & C 1993 & B 1994 & B 1995 & GROUP \\
\hline \multirow{8}{*}{$\begin{array}{l}\text { Negative } \\
n=71\end{array}$} & \multirow{8}{*}{$\begin{array}{l}\text { Positive } \\
n=71\end{array}$} & $\begin{array}{l}\text { Negative } \\
n=25\end{array}$ & & & & DROP OUTS \\
\hline & & Positive & $\begin{array}{l}\text { Negative } \\
n=9\end{array}$ & & & $n=$ \\
\hline & & $n=29$ & $\begin{array}{l}\text { Positive } \\
n=16\end{array}$ & & & \multirow{4}{*}{$\begin{array}{l}\text { BVDV group } \\
n=32\end{array}$} \\
\hline & & & \begin{tabular}{|l} 
Not done \\
$n=4$
\end{tabular} & & & \\
\hline & & \multirow[t]{3}{*}{ Not done } & $\begin{array}{l}\text { Positive } \\
n=4\end{array}$ & & & \\
\hline & & & & $\begin{array}{l}\text { Positive } \\
n=9\end{array}$ & $\begin{array}{l}\text { Positive } \\
n=8\end{array}$ & \\
\hline & & & & & $n=1$ & DROP OUTS \\
\hline & & $n=17$ & $\begin{array}{l}\text { Not done } \\
n=13\end{array}$ & $\begin{array}{l}\text { Negative } \\
n=4\end{array}$ & & $n=5$ \\
\hline \multirow[t]{3}{*}{$\begin{array}{l}\text { Negative } \\
n=84\end{array}$} & \multirow[t]{3}{*}{$\begin{array}{l}\text { Negative } \\
n=84\end{array}$} & \multirow[t]{3}{*}{ Not done } & \multirow[t]{3}{*}{ Not done } & \multirow[t]{2}{*}{$\begin{array}{l}\text { Negative } \\
n=79\end{array}$} & $\begin{array}{l}\text { Negative } \\
n=75\end{array}$ & $\begin{array}{l}\text { Control group } \\
n=75\end{array}$ \\
\hline & & & & & $\begin{array}{l}\text { Positive } \\
n=4\end{array}$ & \\
\hline & & & & $\begin{array}{l}\text { Positive } \\
n=5\end{array}$ & & $\begin{array}{l}\text { DROP OUTS } \\
n=9\end{array}$ \\
\hline
\end{tabular}

$\mathrm{B}=$ Bulk milk.

$\mathrm{H}=$ Pooled milk sample from 3-5 heifers.

$\mathrm{C}=$ Pooles blood sample from 3-5 calves.

\section{Questionnaires and registrations}

All the farmers in both groups received a questionnaire in May 1993 concerning herd size and different management factors such as purchase of animals and use of shared pasture with other herds. The occurrence of abortions, stillbirths, weakly born calves and congenital anomalies during the last 18 months was also registered. The farmers were asked to register such cases also for the following 2 years. In herds which were members of the national milk recording system, percentage of non-return (NR) at 30, 60 and 90 days, average calving interval, number of inseminations per cow, and number of cases treated for metritis, retained placenta and anoestrus were compared. These data are calculated from data registered by the local veterinarians and inseminators in addition to the date of calvings registered by the farmers. For all herds, the first period (1993) of registrations from the national milk recording system included the date of the first positive bulk milk sample (B1993). For most of the herds this registration period started less than 3 months after 
the negative bulk milk sample was collected (B1992), but for 8 herds, this interval was about 6 months. For a period of 3 months between the first and the second registration period, the data from the national milk recording system was not available for most of the herds. The rest of the registrations were done continously.

\section{Statistical analysis}

All the dichotomous variables (yes/no) on animal level were calculated as odds ratios. As denominator was used number of cow equivalents (EQ) registered in the national milk recording system. For the few herds which were not members of this system, the cow EQ given by the farmers were used. It was not possible to get the exact number for all 3 years, so the cow EQ in the second year was used as an estimate for the whole period. Since the first registration in 1993 done by the farmers included a period of 18 months, the number of cow EQ this year was multiplied with a factor of 1.5 when these data were analysed.

For the variables registered on herd level, Student's $t$ test for unpaired data was used. Student's $t$ test for paired data was used to compare the NR within the groups. P-values lower than 0.05 were taken as statistically significant.

\section{Results}

In the BVDV group data of the different variables were available in $53 \%$ to $81 \%$ of the herds (Table 2). In the control group, the different data were available in $49 \%$ to $84 \%$ of the herds. In both groups, data recorded by the national milk recording system were available for a higher percentage of the herds than data registrated by the farmers.

\section{Management factors}

The average herd size was 13.6 cow EQ in the BVDV group, and 11.9 cow EQ in the control group. In both groups, traditional stalls with the cows being tied up in a line were the predominant housing system (Fig. 1). A lower percentage of the BVDV herds compared to the control herds had a concentrated calving season. A higher percentage of the BVDV herds had introduced new animals into the herd the last 18 months before the positive bulk milk sample was taken $(p<0.01)$. A higher rate of the BVDV herds had used pasture shared with other herds, but this difference between the groups was not statistically significant $(p=0.24)$.

\section{Reproduction data}

In the data registered by the farmers, statisti-

Table 2. Number of herds with data for different management and reproduction variables in a BVDV infected group of dairy herds, and a similar BVDV free control group.

\begin{tabular}{|c|c|c|c|c|c|}
\hline & \multirow[b]{2}{*}{ Year } & \multicolumn{2}{|c|}{$\begin{array}{l}\text { BVDV-group } \\
\mathrm{N}=32\end{array}$} & \multicolumn{2}{|c|}{$\begin{array}{l}\text { Control group } \\
\mathrm{N}=75\end{array}$} \\
\hline & & $\mathrm{n}$ & $\%$ & $\mathrm{n}$ & $\%$ \\
\hline Management factors & & $17-19$ & $53-59$ & $38-41$ & $51-55$ \\
\hline $\begin{array}{l}\text { Reproduction parameters } \\
\text { registrated by the farmer }\end{array}$ & $\begin{array}{l}1993 \\
1994 \\
1995\end{array}$ & $\begin{array}{l}19 \\
17 \\
18\end{array}$ & $\begin{array}{l}59 \\
53 \\
56\end{array}$ & $\begin{array}{l}41 \\
37 \\
40\end{array}$ & $\begin{array}{l}55 \\
49 \\
53\end{array}$ \\
\hline $\begin{array}{l}\text { Reproduction parameters } \\
\text { registrated in the national } \\
\text { milk recording system }\end{array}$ & $\begin{array}{l}1993 \\
1994 \\
1995\end{array}$ & $\begin{array}{c}22-26 \\
23-26 \\
22\end{array}$ & $\begin{array}{c}69-81 \\
72-81 \\
69\end{array}$ & $\begin{array}{c}62-63 \\
58-60 \\
61\end{array}$ & $\begin{array}{c}83-84 \\
77-80 \\
81\end{array}$ \\
\hline
\end{tabular}




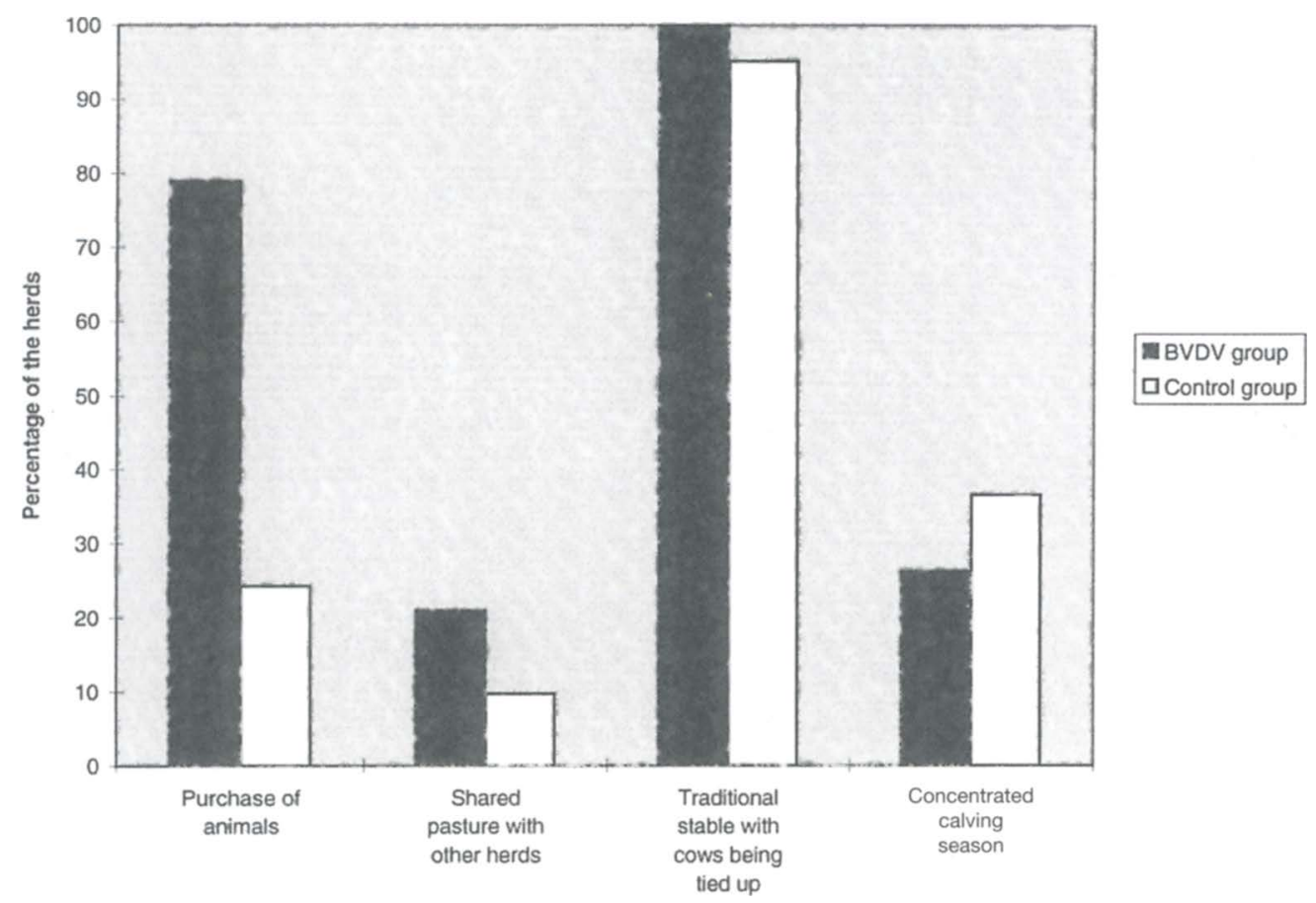

Figure 1. Management factors compared in a BVDV infected group of dairy herds, and in a similar BVDV free control group.

cally significantly more abortions were found in the BVDV group than in the control group. This being the case during the first (1993), and also the second registration period (1994) (Table 3), with odds ratios of 2.57 and 11.63 respectively. For the other variables registered by the farmers, no statistically significant differences were found between the groups. For the parameters "congenital anomalies" and "weakly born calves", the number of cases for each year was so low that statistical calculations could not be carried out. For these parameters the number of cases was summarized for the whole period, without showing any differences between the groups.

Data from the national milk recording system did not show any statistically significant differences between the groups for the NR. The NR for the control group remained stable throughout the study period, but the NR in the BVDV group showed an increase from 1993 to 1995 , which was statistically significant at 60 days (Fig. 2) and 90 days ( $p=0.015$ and 0.016 respectively). The average number of inseminations per cow showed a small numerical difference of 0.1 between the groups the first year, being highest in the BVDV group (Fig. 3) $(p=0.32)$. The average calving interval was all 3 years shorter in the BVDV group than in the control group ( $p<0.01$ for 1995). Both the number of inseminations per cow and the calving interval decreased during the study period in the BVDV group (not statistically significant), but were relatively stable in the control group (Fig. 3).

There was a higher number of cows treated for 
Table 3. Number of abortions, stillbirths, congenital anomalies, and weakly born calves in a BVDV infected group of dairy herds and a similar BVDV free control group.

\begin{tabular}{|c|c|c|c|c|c|c|c|}
\hline & \multirow[b]{2}{*}{ Year } & \multicolumn{2}{|c|}{ BVDV group } & \multicolumn{2}{|c|}{ Control group } & \multirow[b]{2}{*}{ OR } & \multirow[b]{2}{*}{$\mathrm{P}$} \\
\hline & & Cases & $\mathrm{n}$ & Cases & $\mathrm{n}$ & & \\
\hline \multirow[t]{3}{*}{ Abortions } & 1993 & 19 & 394 & 13 & 672 & 2,57 & $<0,01$ \\
\hline & 1994 & 13 & 241 & 2 & 408 & 11,63 & $\ll 0,01$ \\
\hline & 1995 & 8 & 239 & 9 & 440 & 1,66 & 0,30 \\
\hline \multirow[t]{3}{*}{ Stillbirths } & 1993 & 8 & 394 & 9 & 672 & 1,53 & 0,38 \\
\hline & 1994 & 6 & 241 & 7 & 408 & 1,46 & 0,50 \\
\hline & 1995 & 2 & 239 & 8 & 440 & 0,46 & 0,31 \\
\hline Congenital anomalies & 1993-1995 & 5 & 874 & 6 & 1520 & 1,45 & 0,54 \\
\hline Weakly born & 1993-1995 & 1 & 874 & 5 & 1520 & 0,35 & 0,32 \\
\hline
\end{tabular}

$\mathrm{n}=$ number of cow equivalents.

Weakly born $=$ calves that died within the first 2 days of life.

$\mathrm{OR}=$ Odds ratio.

metritis in the BVDV group than in the control group in $1993(\mathrm{p}=0.1), 3.0$ and 0.44 cases per 100 cow EQ, respectively. The number of cows treated for anoestrus and retained placenta was low and not shown to be different in the 2 groups (data not shown).

\section{Discussion}

The strong selection in establishing the BVDV group by excluding all herds with negative results of pooled milk samples from heifers or blood samples from calves, or negative bulk milk sample 1 of the next 2 years, should give a good confidence for presence of recent infection with BVDV in the 32 herds still in the study. Accordingly, it is likely that most of the herds included one or more persistently infected animals for some time, even if it has not been proven that this was the case for all the herds. The first period for registrations done by the farmers (1993) included 18 months up to the start of the study in May 1993. This period included in most cases the whole period between the negative and the positive bulk milk sample and should therefore include the time of introduction of BVDV infection into the herds. With respect to the reproduction parameters registered in the national milk recording system, the first period of registrations (1993) is likely to include the time of infection of the herds, at least in the majority of the herds. There is, however, a possibility that the introduction of BVDV in some herds had taken place prior to the registrations, since the time interval from the negative bulk milk sample to the start of registrations was up to 6 months in 8 of the herds. If this was the case, possible effects of BVDV related to early reproductive failure may have passed unnoticed. This may also be the case for the 3-month period, between the first and the second registration period, when data was not available for the majority of the herds.

The findings of a statistically significant difference between the groups concerning introduction of new animals into the herd and the difference in use of pasture shared with other herds (not statistically significant) are in accordance with what is published about risk factors for herds to acquire BVDV infection (Løken \& 

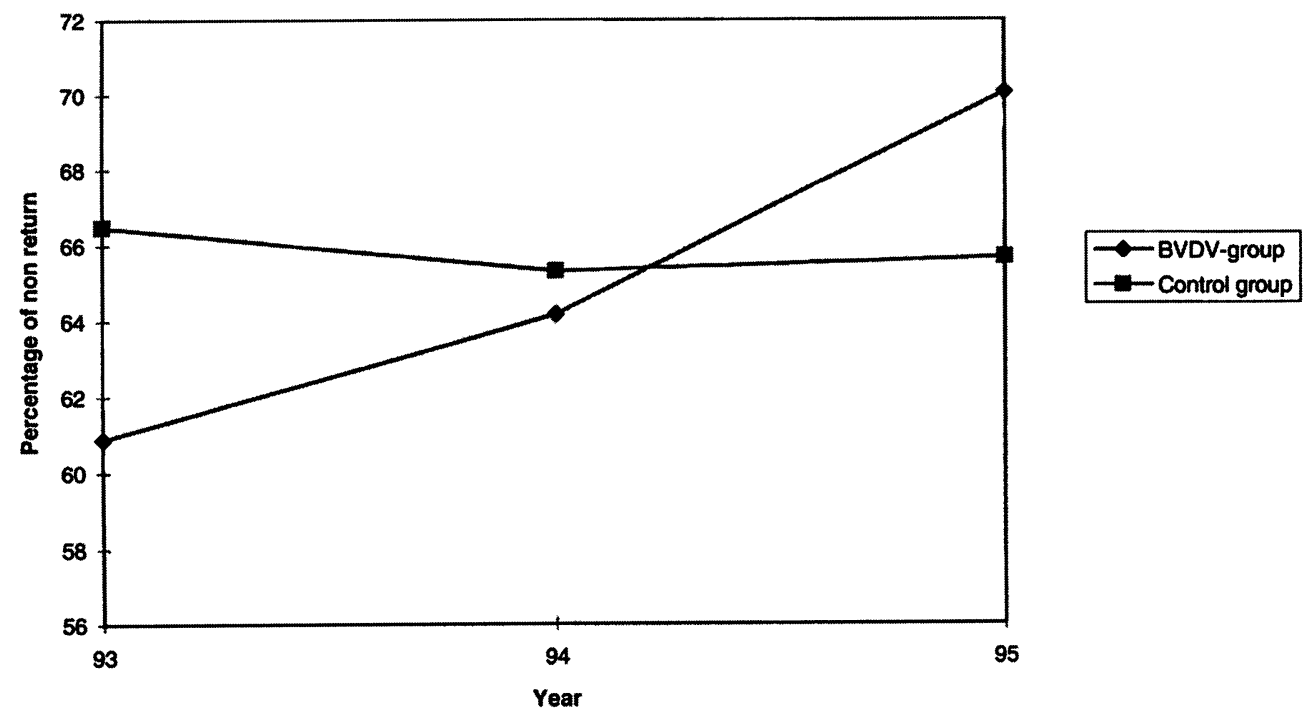

Figure 2. Average percentage of non-return at 60 days in a BVDV infected group of dairy herds, and a similar BVDV free control group.

Daling 1994, Houe 1995, Roeder et al. 1986). The average size of the herds in the BVDV group was slightly larger than in the control group. All together, this indicates that the herds in the BVDV group are managed in a way that implies more contact with other herds than the herds in the control group. There is a possibility that such contact could introduce also other infections that may cause abortions. But since specific infections that are known to cause abortions, like brucellosis and infectious bovine rhinotracheitis, are not diagnosed in Norway, this should not be a major problem.

For all the variables registered on animal level, the correct values would have been achieved using the rate according to the number of calvings for each year. Unfortunately, the number of calvings was not available, and the number of cow EQ is used as a good estimate.

The incidence of abortions in the BVDV group in 1993 and 1994 were 4.8 and 5.4 per 100 cow $\mathrm{EQ}$, respectively. Abortions were registered in
15 of 19 herds during this total period of $2 \frac{1}{2}$ years, but only in 3 of the herds did the number of cases exceed 2 (data not shown). This indicates that the economic loss because of abortions is small for most farmers, but some individual herds are severely affected. For the variables stillbirths, congenital anomalies, and weakly born calves, however, the number of cases was even lower. Accordingly, in this study these effects of BVDV were not found to cause any great economical loss. This is in contrast to results attained by other authors (Woodard 1994, Done et al. 1980, Houe \& Meyling 1991). In the present study, these variables were registered by the farmers, so anomalies not discovered by them were not recorded.

For the length of calving interval, number of inseminations per cow, and NR, there is a trend in the BVDV group for these data to improve through the study, even though only the increase in NR is statistically significant. Analyses were also done by weighting these data for 


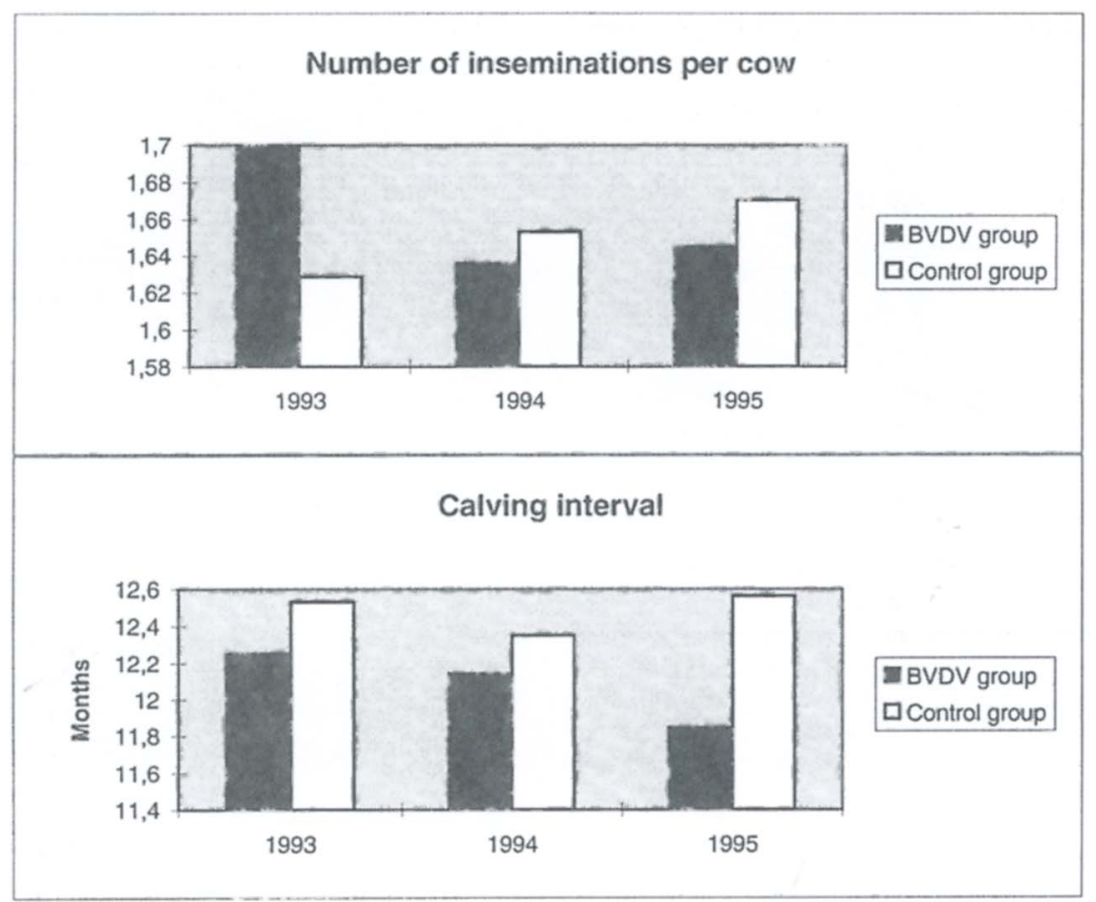

Figure 3. Average number of inseminations per cow, and calving interval in a BVDV infected group of dairy herds, and a similar BVDV free control group.

herd size, but the results differed only imperceptibly from the data shown in Fig. 3. The results might indicate that in the BVDV group the reproduction results altered by the introduction of BVDV into the herds, and that these results during the study period approached the values before this event. Such data in the herds before the infection are unfortunately not available, but might be more favourable than in the control group, where these variables remained relatively stable through the study. Niskanen et al. (1994) did not find any differences between herds recently infected with BVDV and control herds concerning number of inseminations per cow and calving interval, but herds permanently infected with BVDV were shown to have increased calving intervals. Niskanen et al. (1994) also found an association between re- cent infection with BVDV and number of cows treated for retained placenta and oestrus-stimulating treatment. This study did not show any such association, but the total number of cases is small, and the variation within the groups is considerable, so the results should be interpreted with caution. This is also the case for the data concerning cases of metritis.

The exact time of infection in each herd is unknown, and the registration periods may not include the time of infection in all herds. Because of that, some effects of the infection might have passed unnoticed. Even with this reservation, the present study indicates that Norwegian dairy herds infected with BVDV on average suffer a moderate economical loss because of the effect on reproduction during a period of 1 to 2 years, following the introduction of the virus into the 
herd. However, a smaller number of herds are being severely affected. In addition, BVDV does induce economical losses because of other aspects of the infection, such as losses due to mucosal disease and slaughtering of PI calves. However, that is not included in this study.

\section{Aknowledgements}

We are grateful to the Norwegian Control Programme for BVD/MD represented by its leader Ola Nyberg for kindly letting us use data from the programme. The access to data from the national milk recording system has been of great value, and we are grateful for help and cooperation during the work. We also appreciate being allowed to use data from Dag Lindheim's pilot project in Rogaland county, as well as the results of antibody testing done by the Norwegian Cattle Association (NRF), Hamar, concerning the year prior to the start of the national programme.

\section{References}

Baker JC: Bovine viral diarrhea virus: A rewiew. J. Amer. vet. med. Ass. 1987, 190, 1449-1458.

Carlsson U, Fredriksson G, Alenius S, Kindahl H: Bovine virus diarrhoea virus, a cause of early pregnancy failure in the cow. J. vet. Med. A, 1989, 36, 15-23.

Casaro APE, Kendrick JW, Kennedy PC: Response of the bovine fetus to bovine viral diarrhea-mucosal disease virus. Amer. J. vet. Res. 1971, 32, 15431562.

Done JT, Terlecki S, Richardson C, Harkness JW, Sands JJ, Patterson DSP et al.: Bovine virus diarrhoea-mucosal disease virus: Pathogenicity for the fetal calf following maternal infection. Vet. Rec. 1980, 106, 473-479.

Fredriksen B, Løken T, Ødegaard SA: The duration of antibodies against bovine virus diarrhoea virus in bulk milk. Acta vet. scand. 1998, 39, 89-98.

Houe H, Meyling A: Surveillance of cattle herds for bovine virus diarrhoea virus (BVDV)-infection using data on reproduction and calf mortality. Arch. Virol. 1991, Suppl 3, 157-164.

Houe $H$ : Epidemiology of bovine viral diarrhea virus. Vet. Clin. North. Am. Food Anim. Pract. 1995, 11, 521-547.

Juntti N, Larsson B, Fossum C: The use of monoclo- nal antibodies in enzyme linked immunosorbent assay for detection of antibodies to bovine viral diarrhoea virus. J. vet. Med. B, 1987, 34, 356-363.

Kendrick JW: Bovine viral diarrhea-mucosal disease virus infection in pregnant cows. Amer. J. vet. Res. 1971, 32, 561-577.

Løken T, Daling K: Spredning av pestivirus hos storfe på et fellesbeite. (Spread of pestivirus in cattle herds on a common pasture). Norsk Vet. -T. 1994, 106, 7-13.

McGowan MR, Kirkland PD, Richards SG, Littlejohns IR: Increased reproductive losses in cattle infected with bovine pestivirus around the time of insemination. Vet. Rec. 1993, 133, 39-43.

Murray RD: Lesions in aborted bovine fetuses and placenta associated with bovine viral diarrhoea virus infection. Arch. Virol. 1991, Suppl 3, 217224.

Niskanen R, Alenius S, Larsson B, Juntti N: Evaluation of an enzymed-linked immunosorbent assay for detection of antibodies to bovine virus diarrhoea virus in milk. J. vet. Med. B, 1989, 36, 113118.

Niskanen R, Emanuelson U, Sundberg J, Larsson B, Alenius $S$ : Effects of infection with bovine virus diarrhoea virus on health and reproductive performance in 213 dairy herds in one county in Sweden. Prev. Vet. Med. 1994,

Olafson P, MacCallum AD, Fox FH: An apparently new transmissible disease of cattle. Cornell Vet. 1946, 36, 205-213.

Roeder PL, Jeffrey M, Cranwell MP: Pestivirus fetopathogenicity in cattle: Changing sequelae with fetal maturation. Vet. Rec. 1986, 118, 44-48.

Virakul P, Fahning ML, Joo HS, Zemjanis R: Fertility of cows challenged with a cytopathic strain of bovine viral diarrhea virus during an outbreak of spontanous infection with a noncytopathic strain. Theriogenology, 1988, 29, 441-449.

Woodard $L F$ : BVD virus associated with outbreaks of abortion, stillbirths, and weak calves. Vet. Med. 1994, 89, 379-384.

\section{Sammendrag}

Innvirkning av bovin virusdiaré-virus på reproduksjon i nyinfiserte norske melkeku-besetninger.

En gruppe på 32 melkekubesetninger som var nyinfiserte med bovin virusdiaré-virus (BVDV), ble sammenlignet med en kontroll-gruppe bestående av 75 BVDV-frie besetninger. Reproduksjonsparametre ble 
registrert over en periode på 3 år. Resultater fra antistoff-undersøkelser av tankmelk, samlemelk-prøver fra kviger og samle-blodprøver fra ungdyr ble brukt for å velge ut besetningene. Insidensen av aborter var signifikant forskjellig i de 2 gruppene, mens insidensen av dødfødsler, svakfødte kalver og medfødte mis- dannelser ikke var det. Andre variabler som ikkeomløps-prosent, gjennomsnittlig antall inseminasjoner per påbegynt ku og gjennomsnittlig kalvingsintervall viste en tendens til å bedres i løpet av studietiden i BVDV-gruppen, mens de tilsvarende verdier for kontroll-gruppen forble stabile.

Received June 13, 1997; accepted November 10, 1997).

Reprints may be obtained from: Bente Fredriksen, Norwegian College of Veterinary Medicine, Department of Reproduction and Forensic Medicine, P.O. Box 8146 Dep., N-0033 Oslo, Norway.

E-mail: bente.fredriksen@veths.no, tel: +47 229648 85, fax: + 4722597083. 